medRxiv preprint doi: https://doi.org/10.1101/2021.07.19.21257742; this version posted November 15, 2021. The copyright holder for this preprint (which was not certified by peer review) is the author/funder, who has granted medRxiv a license to display the preprint in perpetuity.

All rights reserved. No reuse allowed without permission.

\title{
Identifying Louisiana communities at the crossroads of environmental and social vulnerability, COVID-19, and asthma
}

Arundhati Bakshi*; Alicia Van Doren; Colette Maser; Kathleen Aubin; Collette Stewart; Shannon Soileau; Kate Friedman; Alexis Williams

Section of Environmental Epidemiology and Toxicology, Office of Public Health, Louisiana

Department of Health, Baton Rouge, Louisiana, United States of America

* Corresponding author

Email: Arundhati.Bakshi@LA.gov (AB) 
medRxiv preprint doi: https://doi.org/10.1101/2021.07.19.21257742; this version posted November 15, 2021. The copyright holder for this

\section{Abstract}

2 The COVID-19 pandemic has disproportionately affected the socially and environmentally

3 vulnerable, including through indirect effects on other health conditions. Asthma is one such

4 condition, which may be exacerbated by both prolonged adverse in-home exposures if

5 quarantining in unhealthy homes and prolonged outdoor exposures if the ambient air quality is

6 unhealthy or hazardous. As both are often the case in Environmental Justice (EJ) communities,

7 here we have analyzed data at the census tract (CT) level for Louisiana to assess any correlation

8 between social and environmental vulnerability, and health issues like COVID-19 and asthma.

9 Higher Social Vulnerability Index (SVI), Particulate Matter less than $2.5 \mu \mathrm{m}$ in diameter $\left(\mathrm{PM}_{2.5}\right)$

10 and Ozone levels were associated with higher rates of cumulative COVID-19 incidence at

11 various time points during the pandemic, as well as higher average annual asthma hospitalization

12 rates and estimated asthma prevalence. Further, cumulative COVID-19 incidence during the first

13 three months of the pandemic was moderately correlated with both asthma hospitalizations and

14 estimated prevalence, suggesting similar underlying factors may be affecting both conditions.

15 Additionally, 137 CTs were identified where social and environmental vulnerabilities co-existed,

16 of which $75(55 \%)$ had high estimated prevalence of asthma. These areas are likely to benefit

17 from asthma outreach that considers both social and environmental risk factors. Fifteen out of the

18137 CTs $(11 \%)$ not only had higher estimated prevalence of asthma but also a high burden of

19 COVID-19. Further research in these areas may help to elucidate any common social

20 determinants of health that underlie both asthma and COVID-19 burdens, as well as better clarify

21 the possible role of the environment as related to the COVID-19 burden in Louisiana. 
medRxiv preprint doi: https://doi.org/10.1101/2021.07.19.21257742; this version posted November 15, 2021. The copyright holder for this

\section{Introduction}

23 In 2020, the COVID-19 pandemic laid bare the major health impacts of social and environmental

24 vulnerability, by taking a heavy toll on populations suffering such vulnerabilities. It highlighted

25 how a novel virus does not affect everyone equally; it exploits underlying health conditions that

26 are more prevalent in vulnerable populations [1, 2]. According to the US Centers for Disease

27 Control and Prevention (CDC), asthma is one such respiratory health condition that might be a

28 risk factor for severe illness with COVID-19. It is not only more prevalent among African-

29 Americans and people living in poverty (a population disproportionately affected by COVID-19

$30[3,4])$, but asthma is also heavily influenced by environmental factors [5-7]. As such, it is

31 particularly important to tackle this issue in Environmental Justice (EJ) communities, which lack

32 equitable access to protection from environmental and health hazards, and where socioeconomic,

33 demographic and environmental stressors overlap to create environmental health disparities. For

34 example, many people living in EJ communities do not have access to affordable healthy

35 housing, and thus may be exposed daily to asthma triggers in the home [8]. At a time when

36 people are spending more time in their homes than ever, many asthmatics living in unhealthy

37 homes may experience worsening of their symptoms. People living in communities that have

38 outdoor air concerns may experience prolonged adverse outdoor exposures to known asthma

39 triggers, such as ozone and Particulate Matter less than $2.5 \mu \mathrm{m}$ in diameter $\left(\mathrm{PM}_{2.5}\right)$, if they spend

40 more time socializing outdoors in keeping with COVID-19 safety protocols. These, in turn, could

41 translate into poor outcomes if they contracted COVID-19.

42 The need to tackle this vicious cycle was recently highlighted by a study that showed respiratory

43 health risks from hazardous air pollutants and high incidence of COVID-19 converged in several 
medRxiv preprint doi: https://doi.org/10.1101/2021.07.19.21257742; this version posted November 15, 2021. The copyright holder for this

44 counties across the southeastern United States [9]. These areas tended to have higher non-

45 Hispanic black populations, socioeconomically disadvantaged persons, people with disabilities

46 and people without health insurance. This county-level study served as an important starting

47 point for further exploring the impact of COVID-19 in EJ communities at a finer geographic

48 resolution on a state-by-state basis [9]. Since Louisiana (LA) was one of the states where a

49 majority of counties (called 'parishes' in LA) seemed to fall under the "high-high" category for

50 both respiratory hazard risk and COVID-19 risk, here we have undertaken a census tract (CT)-

51 level analysis to assess any correlation between social and environmental vulnerability, COVID-

52 19, and asthma. We have further identified several EJ communities with a high burden of asthma

53 and COVID-19 where mitigation measures may be targeted, as well as where further studies may

54 be conducted to elucidate the environment's role on COVID-19 outcomes in Louisiana.

\section{Methods}

56 Indicators of social vulnerability

57 To assess social vulnerability, we used the 2018 Social Vulnerability Index (SVI) derived by the

58 CDC Agency for Toxic Substances and Disease Registry (ATSDR) [10]. Along with the Overall

59 SVI, we considered the four specific SVI themes outlined by CDC/ATSDR - socioeconomic

60 status (Theme 1); household composition and disability (Theme 2); minority status and language

61 (Theme 3); and housing type and transportation (Theme 4). We also applied the US Census

62 Bureau's 2018 American Community Survey (ACS) data for percent population without health

63 insurance, below poverty level, unemployed, without a high school diploma, disabled, minority

64 (all persons except non-Hispanic white), age 65+, age 17 and under, and population (age 5+)

65 who speak English "less than well". We also took into account household level information on 
medRxiv preprint doi: https://doi.org/10.1101/2021.07.19.21257742; this version posted November 15, 2021. The copyright holder for this preprint (which was not certified by peer review) is the author/funder, who has granted medRxiv a license to display the preprint in perpetuity.

All rights reserved. No reuse allowed without permission.

those without access to a vehicle, single parent households and households with more people than rooms (crowded homes). Detailed information on each of these variables is available from CDC/ATSDR

\section{(https://www.atsdr.cdc.gov/placeandhealth/svi/documentation/SVI documentation 2018.html).}

All datasets for social vulnerability (Table 1) were considered at the census tract level, and the SVI scores classified into five categories based on the CT's ranking (percentile) against all CTs in the state: $0-0.20 ; 0.21-0.40 ; 0.41-0.60 ; 0.61-0.80 ; 0.81-1.00$. All mapping and spatial analyses were performed in ESRI ArcGIS 10.3.1.

Table 1. Summary of datasets assessed in this study. All datasets were mapped at the census tract level.

\begin{tabular}{|c|c|c|c|}
\hline Topic & Indicator (Measure) & Data Source & $\begin{array}{c}\text { Data } \\
\text { Year(s) }\end{array}$ \\
\hline $\begin{array}{c}\text { Social } \\
\text { Vulnerability }\end{array}$ & $\begin{array}{l}\text { Social Vulnerability Index and related } \\
\text { indicators from ACS } 2018\end{array}$ & CDC/ATSDR & 2018 \\
\hline \multirow{4}{*}{$\begin{array}{l}\text { Environmental } \\
\text { Vulnerability }\end{array}$} & NATA Respiratory Hazard Index & EPA & 2014 \\
\hline & $\begin{array}{l}\mathrm{PM}_{2.5} \text { level (average annual concentration in } \\
\mu \mathrm{g} / \mathrm{m}^{3} \text { ) }\end{array}$ & EPA & 2016 \\
\hline & $\begin{array}{l}\text { Ozone level (summer seasonal average of } \\
\text { daily maximum } 8 \text {-hour concentration in air } \\
\text { in parts per billion) }\end{array}$ & EPA & 2016 \\
\hline & $\begin{array}{l}\text { Indoor mold concerns reported to IEQES } \\
\text { program (average annual number of calls) }\end{array}$ & $\mathrm{LDH}$ & 2017-2019 \\
\hline COVID-19 & $\begin{array}{l}\text { Cumulative COVID-19 incidence rate at 3-, } \\
6-, 9-\text { and 12-month time points }\end{array}$ & $\mathrm{LDH}$ & $\begin{array}{l}\text { Mar 2020- } \\
\text { Mar 2021 }\end{array}$ \\
\hline Asthma & $\begin{array}{l}\text { Asthma Hospitalization (average annual } \\
\text { crude rate, where asthma was a primary } \\
\text { diagnosis among hospitalization cases) }\end{array}$ & $\mathrm{LDH}$ & 2017-2019 \\
\hline
\end{tabular}


medRxiv preprint doi: https://doi.org/10.1101/2021.07.19.21257742; this version posted November 15, 2021. The copyright holder for this

\begin{tabular}{|l|l|l|l|}
\hline & $\begin{array}{l}\text { Estimated Asthma Prevalence (average } \\
\text { annual crude rate, where asthma was any } \\
\text { diagnosis among hospitalization cases) }\end{array}$ & LDH & 2017-2019 \\
\hline
\end{tabular}

\section{Indicators of environmental vulnerability}

78 In terms of environmental datasets (outdoor air), we downloaded the following from US

79 Environmental Protection Agency's (EPA's) EJSCREEN tool version 2020

80 (https://www.epa.gov/ejscreen): National Air Toxics Assessment (NATA) Respiratory Hazard

81 Index (RHI), $\mathrm{PM}_{2.5}$ levels and Ozone levels. The EJSCREEN technical documentation (available

82 from: https://www.epa.gov/sites/production/files/2021-

83 04/documents/ejscreen_technical_document.pdf) provides detailed definitions for each of these

84 measures. Briefly: The RHI is the ratio of the exposure concentration of Hazardous Air

85 Pollutants (HAPs) to a health-based reference concentration. The most recent year of RHI data

86 available (2014) takes into account 181 HAPs (including diesel particulate matter), for which

87 both emissions and health-related toxicity data were available. In order to derive the RHI, US

EPA uses several modeling techniques to estimate both the concentration of the HAPs as well as

the risk of exposure and downstream respiratory health risks. Given that the susceptibility to air

90 pollution cannot be reliably estimated, these models take into consideration differences in

91 emissions and meteorology (which affects the concentration of pollutants in ambient air) and the

92 differences in the location of individuals (which affects exposure) among CTs. Thus, applying

93 these models then allow us to identify geographic patterns and assess relative risks at the CT-

94 level, with the caveat that all calculations become more uncertain with smaller geographies.

95 Complete details on RHI modeling and calculation methods are available from the 2014 NATA

96 Technical Support Document [11]. $\mathrm{PM}_{2.5}$ levels refer to average annual concentrations in $\mu \mathrm{g} / \mathrm{m}^{3}$,

97 as calculated by US EPA using a fusion of modeled and monitored data (for methodological 
medRxiv preprint doi: https://doi.org/10.1101/2021.07.19.21257742; this version posted November 15, 2021. The copyright holder for this preprint (which was not certified by peer review) is the author/funder, who has granted medRxiv a license to display the preprint in perpetuity. All rights reserved. No reuse allowed without permission.

98

99

100

101

102

103

104

105

106

107

108

109

110

111

112

113

114

115

116

117

118

119

details on air quality modeling, see [12]). Ozone levels were similarly calculated using a combination of modeled and monitored data by the EPA [12], using the summer seasonal average of daily maximum 8-hour concentration in air in parts per billion. The most recent data available for both $\mathrm{PM}_{2.5}$ and Ozone levels (2016) was used for this study.

Finally, to account for not only outdoor but also Indoor Environmental Quality (IEQ) concerns, we surveyed internal data from the Louisiana Department of Health's (LDH's) Indoor

\section{Environmental Quality Education Service (IEQES). Since 2000, LDH's IEQES has been}

providing guidance to Louisiana homeowners and renters on a variety of IEQ concerns reported to the program. The majority of these calls $(\sim 75 \%)$ are related to mold in residential settings; however, the IEQES program provides guidance on all types of IEQ issues (including odors, pests, radon, chemical exposures, etc.) in both private and public buildings (such as homes, schools, places of worship, etc.). For this study, we have aggregated the three most recent years of data available through IEQES (2017-2019) and calculated the average annual number of mold concerns reported to the program as an indicator of IEQ concerns in an area. Mold concerns were chosen for this study over all IEQ concerns since they comprised the majority (86\%) of the calls received. Further, mold concerns were most often associated with respiratory complaints (the health focus of this study), as reported by the callers; of the 785 calls that reported respiratory complaints, $708(90 \%)$ were associated with mold. Mold exposure is also recognized as a possible environmental trigger for asthma [13].

All environmental datasets (Table 1) were considered at the census tract level. For all datasets, we used EJSCREEN's visualization method and mapped the RHI, $\mathrm{PM}_{2.5}$, Ozone and IEQ concerns as a percentile score relative to all CTs in the state (ranked using the PERCENTRANK.INC function in MS Excel 2016). A choropleth map was then created using 
medRxiv preprint doi: https://doi.org/10.1101/2021.07.19.21257742; this version posted November 15, 2021. The copyright holder for this

121 progressively darker colors for five categories: $0-20^{\text {th }}$ percentile; $21^{\text {st }}-40^{\text {th }}$ percentile; $41^{\text {st }}-60^{\text {th }}$

122 percentile; $61^{\text {st }}-80^{\text {th }}$ percentile and $81^{\text {st }}-100^{\text {th }}$ percentile.

123 Health indicators (COVID-19 and asthma)

124 Total number of COVID-19 cases by CT were downloaded from LDH's COVID-19 dashboard

125 (https://ldh.la.gov/coronavirus/) and cumulative incidence rates calculated at four time points (3,

1266,9 and 12 months into the pandemic in LA) by dividing the total number of cases at each time

127 point by the ACS 2018 population of the CT. Of the 1145 CTs in LA, data were available for

128 approximately $1034 \mathrm{CTs}$ at the 3-month time point, 1038 at the 6-month time point, and 1039 at

129 the 9- and 12-month time points. Case counts are not provided for CTs with a 2018 population of

130 less than 800 to safeguard privacy.

131 Since asthma surveillance data were not available at the census tract level for most of Louisiana,

132 we estimated asthma burden using the inpatient discharge data available through LDH. To

133 minimize the need for suppression, inpatient discharge data was aggregated for the three most

134 recent years available (2017-2019) and average annual crude rates were calculated for cases

135 where asthma (ICD-10 code J45) was the primary diagnosis, as well as where asthma was any

136 diagnosis. While the former indicated the level of asthma exacerbation in a community that

137 required medical intervention (an indicator for uncontrolled asthma), the latter served as an

138 estimate of asthma prevalence in the community. In order to calculate these, we divided the total

139 number of cases for each CT (2017-2019) by the total population of the CT during that period,

140 and then divided that value by 3 to yield the average annual crude rates.

141 Similar to the environmental vulnerability datasets, percentile scores were also calculated for

142 COVID-19 incidence and asthma data (Table 1), which were then classified in five categories. 
medRxiv preprint doi: https://doi.org/10.1101/2021.07.19.21257742; this version posted November 15, 2021. The copyright holder for this preprint (which was not certified by peer review) is the author/funder, who has granted medRxiv a license to display the preprint in perpetuity.

\section{Correlation analysis}

144 Spearman's Rank Correlation was utilized to analyze the correlation between various social and 145 environmental vulnerability factors, COVID-19 incidence, and the measures of asthma risk by

146 CT. This was performed by first ranking the values in each dataset using RANK.AVG function 147 in MS Excel 2016, followed by applying the PEARSON function to compare two datasets.

148 Significance was set at alpha less than $0.05(\alpha<0.05)$, with degrees of freedom (df) equal to two 149 less than the total number of data points represented in both datasets. Only CTs for which all data 150 were available (1035 out of 1145 total CTs in LA) were used for this analysis. Spearman's rho

151 ( $\rho)$ was used to identify the direction and strength of correlation. If the p-value was less than $1520.05(\mathrm{p}<0.05)$, strength of correlation was defined as follows: absolute value of $\rho=0.01-0.30=$ 153 weakly correlated; $0.31-0.70=$ moderately correlated; and $0.71-1.00=$ strongly correlated. The 154 direction of correlation was determined by the sign (positive or negative) on $\rho$ value.

155 Results

156 Relationship between social and environmental vulnerability, 157 COVID-19, and asthma

CTs were defined as 'high' for social vulnerability if the Overall SVI was greater than or equal 159 to 0.75 , and 'high' for environmental vulnerability if the RHI, $\mathrm{PM}_{2.5}$ level or Ozone level was at or over the $75^{\text {th }}$ percentile for all CTs in the state. When compared to all CTs, high SVI was associated with higher average cumulative COVID-19 incidence rates early in the pandemic (3month and 6-month time points). $\mathrm{PM}_{2.5}$ was associated with lower COVID-19 incidence rates at

163 the 3-month time point, but at 12 months, it was associated with higher COVID-19 incidence. 
medRxiv preprint doi: https://doi.org/10.1101/2021.07.19.21257742; this version posted November 15, 2021. The copyright holder for this preprint (which was not certified by peer review) is the author/funder, who has granted medRxiv a license to display the preprint in perpetuity.

All rights reserved. No reuse allowed without permission.

164 Ozone levels were associated with higher COVID-19 incidence all time points (except at 6

165 months), whereas RHI showed the opposite pattern, being associated with significantly lower

166 COVID-19 incidence at all time points except at 6 months (Fig 1A). Additionally, the COVID-

16719 incidence rates were higher in areas of high SVI + high Ozone compared to areas with only

168 high SVI. This additive effect over SVI was not observed from any other environmental factor,

169 indicating that Ozone may be an important environmental factor affected COVID-19 incidence.

170 With regard to average hospitalization rate for asthma and estimated asthma prevalence, higher

171 rates of both were associated with high SVI and high Ozone levels (Fig 1B). High SVI appeared

172 to have an additive effect on high Ozone, with areas of high SVI + high Ozone having higher

173 asthma hospitalization rate and estimated prevalence than areas that just had high Ozone. Taken

174 together, these descriptive statistics indicated a possible relationship between social and

175 environmental vulnerability (especially related to Ozone), COVID-19, and asthma.

177 Figure 1. COVID-19 and Asthma in areas with high social and/or environmental

178 vulnerability. (A) High SVI was associated with higher average cumulative COVID-19

179 incidence rates early in the pandemic, whereas $\mathrm{PM}_{2.5}$ was associated with higher rates later in the

180 pandemic. Cumulative COVID-19 incidence was elevated in areas of high Ozone at all points

181 during the pandemic. (B) Asthma hospitalization as well as estimated asthma prevalence

182 followed a similar pattern with higher rates of both being associated with high SVI and high

183 Ozone. Error bars indicate $95 \%$ confidence intervals; asterisks $(*)$ indicate areas that are

184 significantly higher than "All CTs" and pounds (\#) indicate areas significantly lower than "All

185 CTs" $(\mathrm{p}<0.05 ;$ T-test $)$. 
medRxiv preprint doi: https://doi.org/10.1101/2021.07.19.21257742; this version posted November 15, 2021. The copyright holder for this preprint (which was not certified by peer review) is the author/funder, who has granted medRxiv a license to display the preprint in perpetuity.

All rights reserved. No reuse allowed without permission.

187 These possible relationships were then further explored in a Spearman rank correlation (Table 2

188

189

190

191

192

193

194

195

196

197

198

199

200

201

202

203

204

205

206

207

208

and 3). Cumulative COVID-19 incidence rate at the 3-month time point was moderately

correlated with the Ozone levels $(\rho=0.32 ; p<0.0001)$, SVI for minority status and language

barriers $(\rho=0.44 ; p<0.0001)$, asthma hospitalization $(\rho=0.32 ; p<0.0001)$, and estimated

prevalence of asthma $(\rho=0.50 ; p<0.0001)$. Asthma hospitalization and estimated prevalence were moderately correlated with SVI for socioeconomic status, SVI for minority and language barriers and Overall SVI $(\rho=0.30-0.37 ; p<0.0001)$. Since one of the strongest correlation coefficients was observed between the estimated prevalence of asthma and cumulative COVID-19 incidence at the 3-month time point, we conducted a second Spearman rank correlation to test whether similar social vulnerability measures may underlie both health indicators (Table 3). According to the results, positive correlations of moderate strength were observed between both health indicators and percent minority population $(\rho=0.51-0.52 ; p<0.0001)$ and percent households without a vehicle $(\rho=0.37-0.44 ; p<0.0001)$.

\section{Table 2. Spearman's rho (correlation coefficient) for social and environmental}

vulnerability, asthma, and COVID-19. With regards to COVID-19, strongest correlation was observed between the cumulative incidence during the first quarter of the pandemic in LA (MarJun 2020) and the estimated prevalence of asthma, SVI due to minority status and language barriers, asthma hospitalization crude rate, and the percentile score for ozone levels. With regards to asthma, SVI due to socioeconomic status, minority status and language barriers, and overall SVI were also significantly correlated with both asthma hospitalization rate as well as the estimated prevalence. 
medRxiv preprint doi: https://doi.org/10.1101/2021.07.19.21257742; this version posted November 15, 2021. The copyright holder for this preprint (which was not certified by peer review) is the author/funder, who has granted medRxiv a license to display the preprint in perpetuity.

All rights reserved. No reuse allowed without permission.

\begin{tabular}{|c|c|c|c|c|c|c|c|}
\hline & & $\begin{array}{l}\text { Hosp. } \\
\text { Asthma }\end{array}$ & $\begin{array}{c}\text { EPV } \\
\text { Asthma }\end{array}$ & $\begin{array}{l}\text { CV19 } \\
\text { (3m) }\end{array}$ & $\begin{array}{l}\text { CV19 } \\
(6 \mathrm{~m})\end{array}$ & $\begin{array}{l}\text { CV19 } \\
(9 \mathrm{~m})\end{array}$ & $\begin{array}{l}\text { CV19 } \\
(12 \mathrm{~m})\end{array}$ \\
\hline \multirow{3}{*}{$\begin{array}{l}\text { Environmental } \\
\text { Factors }\end{array}$} & RHI & -0.02 & 0.04 & -0.12 & -0.05 & -0.14 & -0.14 \\
\hline & Ozone & 0.21 & 0.29 & 0.32 & 0.03 & 0.09 & 0.11 \\
\hline & PM2.5 & 0.08 & 0.02 & -0.07 & -0.02 & 0.12 & 0.08 \\
\hline \multirow{5}{*}{$\begin{array}{c}\text { Social } \\
\text { Vulnerability }\end{array}$} & SVI_SES & 0.36 & 0.34 & 0.22 & 0.15 & -0.16 & -0.24 \\
\hline & SVI_HC & 0.26 & 0.26 & 0.09 & 0.16 & 0.01 & -0.02 \\
\hline & SVI_ML & 0.30 & 0.37 & 0.44 & 0.29 & -0.01 & -0.06 \\
\hline & SVI_HT & 0.13 & 0.09 & 0.11 & 0.19 & 0.02 & -0.07 \\
\hline & SVI_OV & 0.37 & 0.36 & 0.27 & 0.26 & -0.06 & -0.15 \\
\hline \multirow{2}{*}{ Asthma } & Hosp. Asthma & & 0.61 & 0.32 & 0.21 & 0.02 & 0.01 \\
\hline & EPV Asthma & 0.61 & & 0.50 & 0.28 & 0.03 & 0.07 \\
\hline \multirow{4}{*}{$\begin{array}{c}\text { COVID-19 } \\
\text { (cumulative) }\end{array}$} & CV19 (3m) & 0.32 & 0.50 & & & & \\
\hline & CV19 (6m) & 0.21 & 0.28 & & & & \\
\hline & CV19 (9m) & 0.02 & 0.03 & & & & \\
\hline & CV19 (12m) & 0.01 & 0.07 & & & & \\
\hline
\end{tabular}

Abbreviations: $\mathrm{RHI}=$ NATA Respiratory Hazard Index; Ozone $=$ Ozone levels; $\mathrm{PM} 2.5=\mathrm{PM}_{2.5}$ levels; SVI_SOCEC $=$ Social Vulnerability Index (due to socioeconomic factors); SVI_HC $=$ Social Vulnerability Index (due to household composition); SVI_ML = Social Vulnerability Index (due to minority status and language barriers); SVI_HT = Social Vulnerability Index (due to housing and transportation factors); SVI_OV = overall Social Vulnerability Index; Hosp. Asthma = Asthma hospitalization crude rate; EPV Asthma = Estimated prevalence of asthma; CV19 = Cumulative COVID-19 incidence at 3, 6, 9 and 12 months

\begin{tabular}{|l|l|}
\hline Legend based on rho value: & Strength and direction of correlation: \\
\hline$>0.7$ to 1.0 & Strongly positive correlation \\
\hline$>0.3$ to 0.7 & Moderately positive correlation \\
\hline$>0$ to 0.3 & Weakly positive correlation \\
\hline Rho $=0$ or $p \geq 0.05$ & No significant correlation \\
\hline$<0$ to -0.3 & Weakly negative correlation \\
\hline$<-0.3$ to $-\mathbf{0 . 7}$ & Moderately negative correlation \\
\hline$<-0.7$ to $-\mathbf{1 . 0}$ & Strongly negative correlation \\
\hline
\end{tabular}

211 asthma and COVID-19. Statistically significant correlations were observed between several

212 vulnerability factors and cumulative COVID-19 incidence up to June 2020 (CV19 [3m]) and/or

213 estimated prevalence of asthma (EPV Asthma). However, the factors that showed moderately 
medRxiv preprint doi: https://doi.org/10.1101/2021.07.19.21257742; this version posted November 15, 2021. The copyright holder for this preprint (which was not certified by peer review) is the author/funder, who has granted medRxiv a license to display the preprint in perpetuity.

All rights reserved. No reuse allowed without permission.

strong correlation coefficients with both health indicators were percent minority populations and

percent households without a vehicle.

\begin{tabular}{|c|c|c|c|}
\hline & $\begin{array}{c}\text { EPV } \\
\text { Asthma }\end{array}$ & $\begin{array}{l}\text { CV19 } \\
(3 \mathrm{~m})\end{array}$ & $\begin{array}{l}\text { Abbreviations: } \\
\mathrm{PP} / \mathrm{H} / \mathrm{U}=\text { Percent Population/Household/Housing Unit }\end{array}$ \\
\hline PP_AGE17 & 0.01 & -0.06 & AGE17 = Age 17 and under; \\
\hline PP_UNINSUR & 0.23 & 0.18 & UNINSUR = No health insurance; \\
\hline PP_POV & 0.31 & 0.23 & POV = Below poverty; \\
\hline PP_UNEMP & 0.29 & 0.16 & UNEMP = Unemployed; \\
\hline PP_NOHSDP & 0.28 & 0.17 & NOHSDP = No high school diploma; \\
\hline PP_AGE65 & -0.01 & 0.01 & AGE65 = Age 65 and over; \\
\hline PP_DISABL & 0.29 & 0.05 & DISABL = Disabled; \\
\hline PP_MINRTY & 0.51 & 0.52 & MINRTY = Minority; \\
\hline PP_LIMENG & 0.10 & 0.18 & LIMENG = Limited English; \\
\hline PH_SNGPNT & 0.27 & 0.20 & SNGPNT = Single parent households; \\
\hline PU_CROWD & 0.06 & 0.01 & CROWD = Crowded housing units; \\
\hline PH_NOVEH & 0.44 & 0.37 & NOVEH = Households without vehicle; \\
\hline PP_GROUPQ & -0.06 & 0.07 & GROUPQ = Living in group quarter; \\
\hline \multicolumn{3}{|c|}{ Legend based on rho value: } & Strength and direction of correlation: \\
\hline \multicolumn{3}{|l|}{$>0.7$ to 1.0} & Strongly positive correlation \\
\hline \multicolumn{3}{|l|}{$>0.3$ to 0.7} & Moderately positive correlation \\
\hline \multicolumn{3}{|l|}{$>0$ to 0.3} & Weakly positive correlation \\
\hline \multicolumn{3}{|c|}{ Rho $=0$ or $p \geq 0.05$} & No significant correlation \\
\hline \multicolumn{3}{|l|}{$<0$ to -0.3} & Weakly negative correlation \\
\hline \multicolumn{3}{|l|}{$<-0.3$ to -0.7} & Moderately negative correlation \\
\hline \multicolumn{3}{|l|}{$<-0.7$ to -1.0} & Strongly negative correlation \\
\hline
\end{tabular}

219 Surveying the spatial distribution of statewide social vulnerability data showed that while most

220 LA parishes (59/64) had one or more CTs with high overall SVI, i.e. SVI>=0.75 (Fig 2A),

221 environmental vulnerability factors were more likely to be high (at or above the $75^{\text {th }}$ percentile) 
medRxiv preprint doi: https://doi.org/10.1101/2021.07.19.21257742; this version posted November 15, 2021. The copyright holder for this preprint (which was not certified by peer review) is the author/funder, who has granted medRxiv a license to display the preprint in perpetuity. All rights reserved. No reuse allowed without permission.

222 in certain specific parts of the state. Ozone levels, for instance, were higher in the north,

223 northwest and southeast (Fig 2B); $\mathrm{PM}_{2.5}$ levels were higher in the north, northwest and east (Fig

224 2C); and RHI was higher in the northwest, southwest and eastern parts of the state (map not

225 shown). In terms of IEQ issues, at least one mold concern was reported from 542 CTs in LA (Fig

226 2D), 301 of which (55\%) also had high RHI, high $\mathrm{PM}_{2.5}$ or high Ozone levels. These CTs, where

227 both indoor and outdoor environments may be of concern, were present in pockets but

228 distributed across the state. A similar inspection of the health measures (asthma and COVID-19)

229 revealed that they were most often noted as 'high' (at or above the $75^{\text {th }}$ percentile for the state) in 230 northwestern and southeastern parts of the state (Fig 2E-F). northwest and southeastern parts of the state. Indoor environmental quality concerns (mostly in the form of mold complaints) were also reported from all over the state (D). Estimated

237 prevalence of asthma (E) was often above the median in census tracts located in the

238 northwestern, western, southern and southeastern parishes. At the 12-month time point, 239 cumulative COVID-19 incidence rates (F) were higher in the northern, northwestern and 240 southeastern parts of the state.

242 Next, we attempted to identify EJ communities in Louisiana using the social and environmental 243 vulnerability metrics. We used Overall SVI from CDC/ATSDR as the overarching metric for 
medRxiv preprint doi: https://doi.org/10.1101/2021.07.19.21257742; this version posted November 15, 2021. The copyright holder for this preprint (which was not certified by peer review) is the author/funder, who has granted medRxiv a license to display the preprint in perpetuity.

All rights reserved. No reuse allowed without permission.

244 social vulnerability. For environmental vulnerability, we chose RHI, $\mathrm{PM}_{2.5}$ and Ozone levels.

245 IEQ reports were not considered because of the sparse nature of the data. Thus, we intersected

246 Overall SVI, RHI, $\mathrm{PM}_{2.5}$ and Ozone datasets (Fig 3A), and defined a CT as an area of EJ concern

247 if along with high SVI, it also had either high RHI, high $\mathrm{PM}_{2.5}$ or high Ozone levels. Mapping

248 these areas revealed that the 137 CTs that fit these criteria were mostly located in the major

249 urban centers with a few spread across the more rural areas of the state (Fig 3B).

Figure 3. Identifying census tracts with EJ concerns. Census Tracts were defined as being of

EJ concern if the Overall SVI was at or above the $75^{\text {th }}$ percentile, along with at least one of the

253 environmental variables (RHI, $\mathrm{PM}_{2.5}$ or Ozone) at or above the $75^{\text {th }}$ percentile for the state (A).

254 Map shows the number of the CTs of EJ concern by Parish (B). Most of them were located in the

255 major urban areas, with a few spread across the rural areas of the state.

257 Finally, we surveyed the health metrics of these EJ CTs and sought to identify areas of high

258 asthma and COVID-19 burden (Fig 4A). Out of the 137 EJ CTs, 75 (55\%) had high estimated

259 asthma prevalence (at or above the $75^{\text {th }}$ percentile for the state), $28(20 \%)$ had a high cumulative

260 COVID-19 rates at the 12-month time point, and 15 CTs (11\%) had a high burden of both

261 asthma and COVID-19. The 75 EJ CTs with a high burden of asthma were mostly located in the

262 major urban centers of the state, with a few in the more rural areas (Fig 4B). A similar pattern

263 was observed for the 15 EJ CTs with a high burden of both asthma and COVID-19, with a third

264 of them being located in the northwestern part of the state in Caddo Parish (Fig 4C). 
medRxiv preprint doi: https://doi.org/10.1101/2021.07.19.21257742; this version posted November 15, 2021. The copyright holder for this preprint (which was not certified by peer review) is the author/funder, who has granted medRxiv a license to display the preprint in perpetuity.

Over the past year, COVID-19 has taken a disproportionate toll on minority populations across the country, shining a spotlight on the health, socioeconomic and environmental disparities faced to severe, may be a risk factor for severe illness with COVID-19. It is also a respiratory health condition that disproportionately affects racial and ethnic minorities [14]. Here we show that these trends in health disparities, previously assessed nationally and/or at the county level [3, 9 , $14,15]$, hold true at the census tract level in Louisiana. Specifically, our data show a moderately strong positive correlation between SVI due to minority status/language barrier and three health

283 data variables: asthma hospitalization; estimated asthma prevalence; and cumulative COVID-19

284 incidence at 3 months (Table 2). Interestingly, SVI measures were either negatively or not 285 significantly correlated COVID-19 incidence at the 9- and 12-month time points, indicating that social vulnerability factors may have played a greater role in COVID-19 spread early in the 
medRxiv preprint doi: https://doi.org/10.1101/2021.07.19.21257742; this version posted November 15, 2021. The copyright holder for this preprint (which was not certified by peer review) is the author/funder, who has granted medRxiv a license to display the preprint in perpetuity. All rights reserved. No reuse allowed without permission.

287 288

pandemic, but may have been of diminishing importance as the pandemic wore on (Fig 1 and Table 2).

Regardless, an assessment of specific social vulnerability factors, asthma and COVID-19 is likely to reveal important characteristics of minority populations that have contributed to longstanding health disparities along racial and socioeconomic lines. One such characteristic may be lack of access to a vehicle. (Table 3). This may be of particular importance in Louisiana, which lacks extensive public transport infrastructure in most places, and may be a factor that prevents people from accessing areas away from their immediate vicinity to acquire healthcare services, or other commodities conducive to health (such as healthy foods, if living in a food desert). In urban areas, where public transport is available, people without vehicles may not be able to socially distance in the confined space while using public transportation. Indeed, a connection between higher subway ridership and COVID-19 infection risk was observed in a previous study in New York [16], and has been suggested previously in an earlier sub-county study in Louisiana measuring Area Deprivation Index and COVID-19 risk [17]. Thus, the possible impact of not having access to a vehicle (among other vulnerability factors) on chronic health conditions, as well as COVID-19 spread, warrants further investigation, especially in Louisiana's minority communities that face other socioeconomic and environmental stressors as well.

Minorities, especially African-Americans, are also more likely to live in EJ communities and be exposed to environmental pollutants that can influence their health [18]. Asthma is a respiratory condition that has several known environmental triggers such as ozone and particulate matter. Various studies have also shown that there may be a connection between air pollutants affecting respiratory health (mainly, particulate matter) and COVID-19 incidence as well as mortality $[9$, $15,19,20]$. In our study, however, we found higher rates of COVID-19 incidence, asthma 
medRxiv preprint doi: https://doi.org/10.1101/2021.07.19.21257742; this version posted November 15, 2021. The copyright holder for this preprint (which was not certified by peer review) is the author/funder, who has granted medRxiv a license to display the preprint in perpetuity. All rights reserved. No reuse allowed without permission.

hospitalizations and estimated asthma prevalence in CTs with higher ozone levels (Fig 1 and Table 2). According to the US EPA, long-term exposure to ozone pollution can damage the lungs and make it likely to acquire respiratory tract infections [21,22]. Ozone is also known to aggravate asthma and may be one of the factors that leads to developing asthma [23-26]. Of note, a 2018 study showed that exposure to even low levels of ozone (below the limit set by the National Ambient Air Quality Standards) had adverse effects on the respiratory health of African-American children with poorly-controlled asthma [27]. Since ground-level ozone is formed from precursors present in traffic exhaust and industrial emissions, it is possible that ozone levels may be higher in the more urban, industrialized areas of Louisiana than the more rural regions, as has been previously documented by CDC for the entire United States [28]. If this assumption holds true, it would explain our results indicating that CTs with EJ concerns are largely located in the more urban areas of the state (Fig 3). Thus, any possible contribution of ozone to asthma prevalence, asthma exacerbation as well as the COVID-19 burden in Louisiana bears investigation in the areas of concern.

Since about $60 \%$ of the CTs with EJ concerns related to outdoor air also reported IEQ concerns (primarily, mold in homes), the 116 tracts identified to be of concern with regards to asthma (Fig 4A) may benefit from educational outreach that includes both clinical and environmental management of asthma [29-32]. To accommodate individuals with asthma who may not have access to vehicles for easy transportation, we propose either a local community-based or a homebased education model that ideally incorporates an environmental evaluation of their home. Such initiatives are not only likely to reduce respiratory health disparities in LA, but they may also open the door to further research that establish the factors underlying both COVID-19 incidence and asthma prevalence (Table 2), the potential environmental impact on both health indicators, 
medRxiv preprint doi: https://doi.org/10.1101/2021.07.19.21257742; this version posted November 15, 2021. The copyright holder for this preprint (which was not certified by peer review) is the author/funder, who has granted medRxiv a license to display the preprint in perpetuity. All rights reserved. No reuse allowed without permission.

333 as well as any increased burden of asthma due to COVID-19 in EJ communities. Considering the 334 fact that much of the adverse impact from COVID-19 on vulnerable populations may have been 335 through pre-existing disparities in chronic health outcomes $[1,2]$, such initiatives focusing on 336 improving health and environmental equity are likely to yield long-term gains.

337 Our study is the first to our knowledge that evaluates the intersection of social and environmental 338 vulnerability, COVID-19 and asthma statewide at the census tract level in LA. Thus, it represents 339 an important milestone in identifying and understanding specific communities that are at the 340 crossroads of environmental justice issues as well as health disparities. However, there are some 341 important limitations that should be considered. First, it is an ecological study, and therefore, 342 while providing useful observational data to help generate hypotheses, it cannot be used to test 343 any hypothesis related to population health. Second, though we chose the most current environmental vulnerability metrics available from EPA EJSCREEN, we cannot be certain that they model current environmental conditions. At the same time, much of the impact of air 346 pollution on respiratory health is due to long-term exposure [23-27], not just short-term;

347 therefore, it is still instructive to consider these data even if it is a few years old as of 2021.

348 Third, there are multiple different models for estimating the burden of air pollution; all have their 349 own pros and cons, and all are relatively more unstable at smaller geographic levels (such as sub350 county geographies). The environmental vulnerability metrics and visualization scheme 351 presented here were based on those used by a well-established resource to study environmental 352 justice concerns (EJSCREEN). However, we cannot rule out that using different models of air 353 pollution estimates or applying the same models but at a different spatial resolution may yield 354 different results. Finally, due to the lack of outpatient asthma surveillance data at the sub-county 355 level, we used inpatient discharge data to estimate the burden of asthma hospitalization as well as 
medRxiv preprint doi: https://doi.org/10.1101/2021.07.19.21257742; this version posted November 15, 2021. The copyright holder for this preprint (which was not certified by peer review) is the author/funder, who has granted medRxiv a license to display the preprint in perpetuity.

All rights reserved. No reuse allowed without permission.

estimated asthma prevalence. These data are subject to various limitations that result from incomplete reporting, changes in hospital administration (such as closures or merges), inequities in healthcare access, choice of diagnosis codes, etc. Complete metadata related to asthma hospitalizations can be found through the LDH website (https://ldh.la.gov/assets/oph/CenterEH/envepi/EPHT/Infotab-Metadata/Asthma_5-1-2019.pdf).

\section{Conclusion}

In the wake of COVID-19, there has been a spotlight on health disparities due to social and environmental vulnerability often faced by people living in EJ communities. Given that Louisiana has a high burden of both EJ and health concerns, we examined these relationships in Louisiana at the census tract level and at four different time points during the pandemic. The results show that CTs with high SVI, high $\mathrm{PM}_{2.5}$ and high Ozone levels had a higher burden of asthma and/or COVID-19, but the relationships only held true at certain time points (Fig 1, Fig 2 and Table 2). Moreover, one of the strongest correlation coefficients was observed between COVID-19 incidence at 3 months and the estimated prevalence of asthma, indicating similar vulnerability factors may be influencing both health outcomes (Fig 2). In terms of where the areas of concern were located, we identified $137 \mathrm{CTs}$, most of which were concentrated in the major urban centers of the state (Fig 3). Of note, 75/137 CTs (55\%) had a high burden of asthma and 15/137 (11\%) had a high burden of COVID-19 as well as asthma (Fig 4). Based on the results presented here, we propose that further research is warranted into the impact of COVID19 in EJ areas, specifically as it relates to ozone exposure. Currently, much of the environmental focus of the pandemic remains on $\mathrm{PM}_{2.5}$ levels; however, we noted that higher levels of ozone was consistently associated with higher incidence rates of COVID-19, and it was the only 
medRxiv preprint doi: https://doi.org/10.1101/2021.07.19.21257742; this version posted November 15, 2021. The copyright holder for this preprint (which was not certified by peer review) is the author/funder, who has granted medRxiv a license to display the preprint in perpetuity. All rights reserved. No reuse allowed without permission.

378

379

380

381

382

383

384

385

386

387

388

389

390

391

392

393

394

395

environmental factor that appeared to have an additive effect over SVI on COVID-19 incidence

(Fig 1). Given ozone's ability to damage lungs over time, contribute to the both development and exacerbation of asthma, as well as render people more susceptible to infections, we propose that more research is needed to elucidate the role of ozone on COVID-19 outcomes. From a public health standpoint, more programs and policies may be helpful that help people in EJ communities overcome their health, social and environmental challenges. Examples include those that assist with improved access to healthcare, transportation, healthy foods, better employment opportunities, healthy housing, air quality monitoring, and environmental health education, among others. Considering the adverse impact of the pandemic on vulnerable communities facing long-standing disparities in health and environment, programs such as these (and further data that support their efficacy) are likely to be important not only for improving health equity but also future pandemic preparedness for the entire nation.

\section{Acknowledgements}

We extend our sincere thanks to the LDH Section of Infectious Disease Epidemiology and Bureau of Health Informatics for their tireless efforts and dedication at gathering and publishing reliable health data for the State of Louisiana, while simultaneously tackling the COVID-19 pandemic.

\section{References}

1. Alcendor DJ. Racial Disparities-Associated COVID-19 mortality among minority populations in the US. J Clin Med. 2020; 9:2442. 
medRxiv preprint doi: https://doi.org/10.1101/2021.07.19.21257742; this version posted November 15, 2021. The copyright holder for this preprint (which was not certified by peer review) is the author/funder, who has granted medRxiv a license to display the preprint in perpetuity.

All rights reserved. No reuse allowed without permission.

400

401

402

403

404

405

406

407

408

409

410

411

412

413

414

415

416

417

418

419

2. Moore JT, Pilkington W, Kumar D. Diseases with health disparities as drivers of COVID $\square 19$ outcome. J Cell Mol Med. 2020; 24: 11038-11045.

3. Cyrus E, Clarke R, Hadley D, Bursac Z, Trepka MJ, Dévieux JG, et al. The impact of COVID-19 on African American communities in the United States. Health Equity. 2020; 4:476-483.

4. Abedi V, Olulana O, Avula V, Chaudhary D, Khan A, Shahjouei S, et al. Racial, economic, and health inequality and COVID-19 infection in the United States. J Racial Ethn Health Disparities. 2020; 1:1-11.

5. Fitzpatrick AM, Gillespie SE, Mauger DT, Phillips BR, Bleecker ER, Israel E, et al. Racial disparities in asthma-related health care use in the National Heart, Lung, and Blood Institute's Severe Asthma Research Program. J Allergy Clin Immunol. 2019; $143: 2052-2061$.

6. Moorman JE, Akinbami LJ, Bailey CM, Zahran HS, King ME, Johnson CA, et al. National Surveillance of Asthma: United States, 2001-2010. National Center for Health Statistics. Vital Health Stat. 2012; 3. Available from: https://www.cdc.gov/nchs/data/series/sr 03/sr03 035.pdf.

7. Nishimura KK, Galanter JM, Roth LA, Oh SS, Thakur N, Nguyen EA, et al. Early-life air pollution and asthma risk in minority children: The GALA II and SAGE II studies. Am J Respir Crit Care Med. 2013; 188:309-318.

8. Pacheco CM, Ciaccio CE, Nazir N, Daley CM, DiDonna A, Choi WS, et al. Homes of low-income minority families with asthmatic children have increased condition issues. Allergy Asthma Proc. 2014; 35:467-74. 
medRxiv preprint doi: https://doi.org/10.1101/2021.07.19.21257742; this version posted November 15, 2021. The copyright holder for this preprint (which was not certified by peer review) is the author/funder, who has granted medRxiv a license to display the preprint in perpetuity.

All rights reserved. No reuse allowed without permission.

9. Chakraborty J. Convergence of COVID-19 and chronic air pollution risks: Racial/ethnic and socioeconomic inequities in the U.S. Environ Res. 2021; 193:110586.

10. Centers for Disease Control and Prevention/ Agency for Toxic Substances and Disease Registry/ Geospatial Research, Analysis, and Services Program. CDC Social Vulnerability Index 2018 Database, Louisiana [cited 2021 May 17]. Available from: https://www.atsdr.cdc.gov/placeandhealth/svi/data_documentation_download.html

11. Office of Air Quality Planning and Standards, Environmental Protection Agency. Technical Support Document: EPA’s 2014 National Air Toxics Assessment [cited 2021 May 17]. Available from: https://www.epa.gov/sites/production/files/201809/documents/2014 nata technical support document.pdf.

12. Reff A, Phillips S, Eyth A, Mintz D. Bayesian space-time downscaling fusion model (downscaler)-derived estimates of air quality for 2011. U.S. Environmental Protection Agency, Office of Air Quality Planning and Standards, Air Quality Assessment Division. 2015; EPA/454/S-15/001. Available from: https://nepis.epa.gov/Exe/ZyPDF.cgi?Dockey=P100OORX.PDF.

13. Zhang Z, Reponen T, Hershey GK. Fungal exposure and asthma: IgE and non-IgEmediated mechanisms. Curr Allergy Asthma Rep. 2016; 16:86.

14. Centers for Disease Control and Prevention. 2018 National Health Interview Survey (NHIS) Data [cited 2021 May 17]. Available from: https://www.cdc.gov/asthma/nhis/2018/data.htm

15. Terrel K and James W. Racial disparities in air pollution burden and COVID-19 deaths in Louisiana, USA, in the context of long-term changes in fine particulate pollution. Environ. Justice. 2020; online ahead of print. 
medRxiv preprint doi: https://doi.org/10.1101/2021.07.19.21257742; this version posted November 15, 2021. The copyright holder for this preprint (which was not certified by peer review) is the author/funder, who has granted medRxiv a license to display the preprint in perpetuity.

All rights reserved. No reuse allowed without permission.

16. Carrion D, Colicino E, Pedretti NF, Arfer KB, Rush J, DeFelice N, et al. Assessing capacity to social distance and neighborhood-level health disparities during the COVID19 pandemic. medRxiv v2 [Preprint]. 2020 [cited 2021 October 26]. Available from: https://doi.org/10.1101/2020.06.02.20120790.

17. Madhav KC, Oral E, Straif-Bourgeois S, Rung AL, Peters ES. The effect of area deprivation on COVID-19 risk in Louisiana. PLoS One. 2020; 15:e0243028.

18. Bullard RD. Race and environmental justice in the United States. Yale J Int Law. 1993; Available from: https://digitalcommons.law.yale.edu/yjil/vol18/iss1/12.

19. Wu X, Nethery RC, Sabath MB, Braun D, Dominici F. Air pollution and COVID-19 mortality in the United States: Strengths and limitations of an ecological regression analysis. Sci Adv. 2020; 6:eabd4049.

20. Hendryx M, Luo J. COVID-19 prevalence and fatality rates in association with air pollution emission concentrations and emission sources. Environ. Pollut. 2020; 265(Part A):115126.

21. Al-Hegelan M, Tighe RM, Castillo C, Hollingsworth JW. Ambient ozone and pulmonary innate immunity. Immunol Res. 2011; 49: 173-191.

22. Kesic MJ, Meyer M, Bauer R, Jaspers I. Exposure to ozone modulates human airway protease/antiprotease balance contributing to increased Influenza A infection. PLoS One. 2012; 7: e35108.

23. To T, Zhu J, Stieb D, Gray N, Fong I, Pinault L, et al. Early life exposure to air pollution and incidence of childhood asthma, allergic rhinitis and eczema. Eur Respir J. 2020; 55:1900913. 
medRxiv preprint doi: https://doi.org/10.1101/2021.07.19.21257742; this version posted November 15, 2021. The copyright holder for this preprint (which was not certified by peer review) is the author/funder, who has granted medRxiv a license to display the preprint in perpetuity.

All rights reserved. No reuse allowed without permission.

24. Chatkin J, Correa L, Santos U. External environmental pollution as a risk factor for asthma. Clinic Rev Allerg Immunol. 2021; Available from: https://doi.org/10.1007/s12016-020-08830-5.

25. Tiotiu AI, Novakova P, Nedeva D, Chong-Neto HJ, Novakova S, Steiropoulos P, et al. Impact of air pollution on asthma outcomes. Int J Environ Res Public Health. 2020; 17: 6212.

26. Anenberg SC, Henze DK, Tinney V, Kinney PL, Raich W, Fann N, et al. Estimates of the global burden of ambient $\mathrm{PM}_{2.5}$, ozone, and $\mathrm{NO}_{2}$ on asthma incidence and emergency room visits. Environ Health Perspect. 2018; 126: 107004.

27. Hernandez M, Dhingra R, Burbank A, Todorich K, Loughlin C, Frye M, et al. Low level ozone has both respiratory and systemic effects in African-American adolescents with asthma despite asthma controller therapy. J Allergy Clin Immunol. 2018; 142:19741977.e3.

28. Strosnider H, Kennedy C, Monti M, Yip F. Rural and urban differences in air quality, 2008-2012, and community drinking water quality, 2010-2015 — United States. MMWR Surveill Summ. 2017; 66:1-10.

29. Marshall ET, Guo J, Flood E, Sandel MT, Sadof MD, Zotter JM. Home visits for children with asthma reduce Medicaid costs. Prev Chronic Dis. 2020; 17:190288.

30. Campbell JD, Brooks M, Hosokawa P, Robinson J, Song L, Krieger J. Community Health Worker home visits for Medicaid-enrolled children with asthma: Effects on asthma outcomes and costs. Am J Public Health. 2015; 105:2366-2372. 
medRxiv preprint doi: https://doi.org/10.1101/2021.07.19.21257742; this version posted November 15, 2021. The copyright holder for this preprint (which was not certified by peer review) is the author/funder, who has granted medRxiv a license to display the preprint in perpetuity. All rights reserved. No reuse allowed without permission.

486

487

488

489
31. National Center for Healthy Housing. Case Studies: The benefits of home visits for children with asthma. Available from: https://nchh.org/resource-library/case-studies thebenefits-of-home-visits-for-children-with-asthma.pdf

32. Bryant-Stephens T, Reed-Wells S, Canales M, Perez L, Rogers M, Localio AR, et al. Home visits are needed to address asthma health disparities in adults. J Allergy Clin Immunol. 2016; 138:1526-1530. 


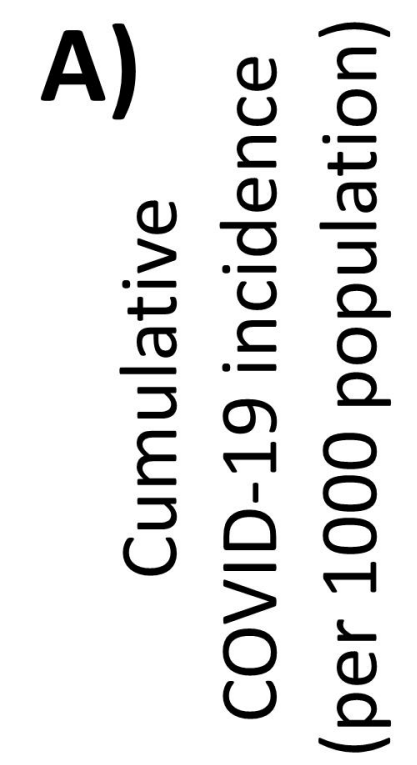

B)

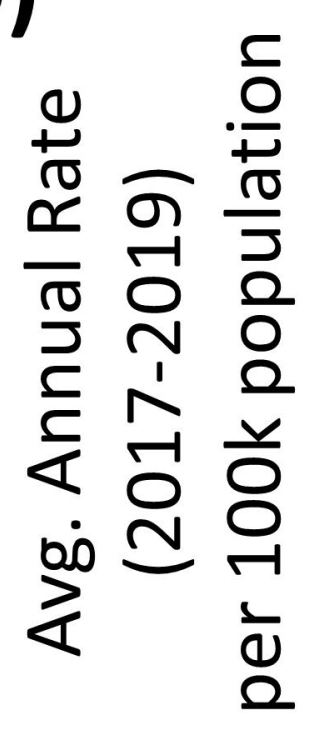

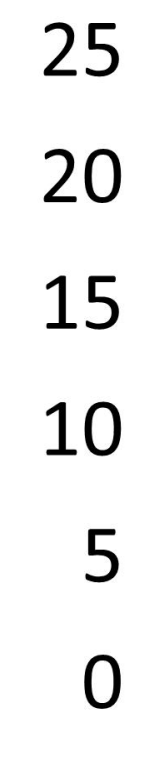

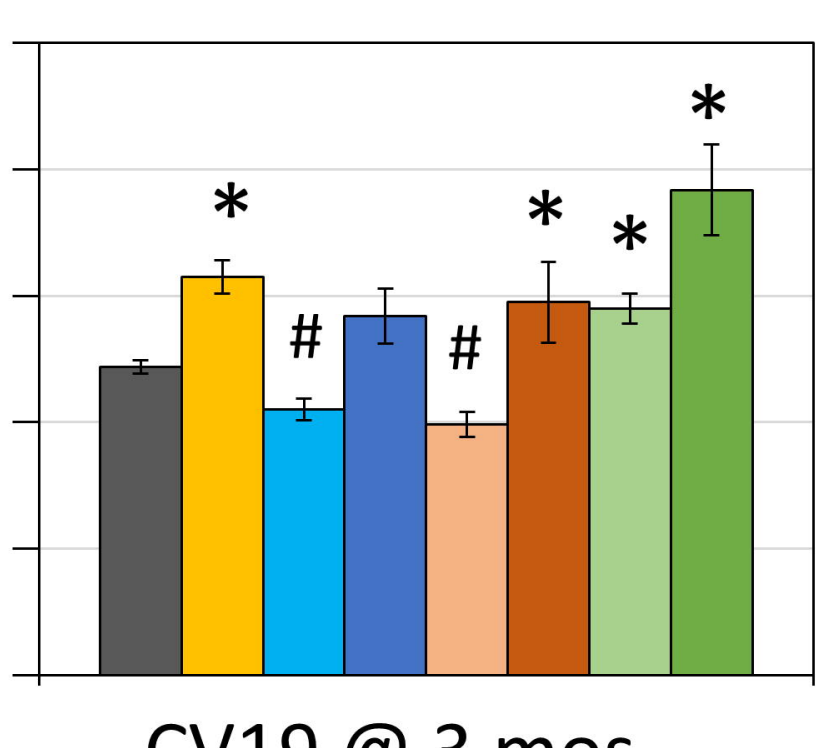

CV19@3 mos.

(Mar-Jun 2020)

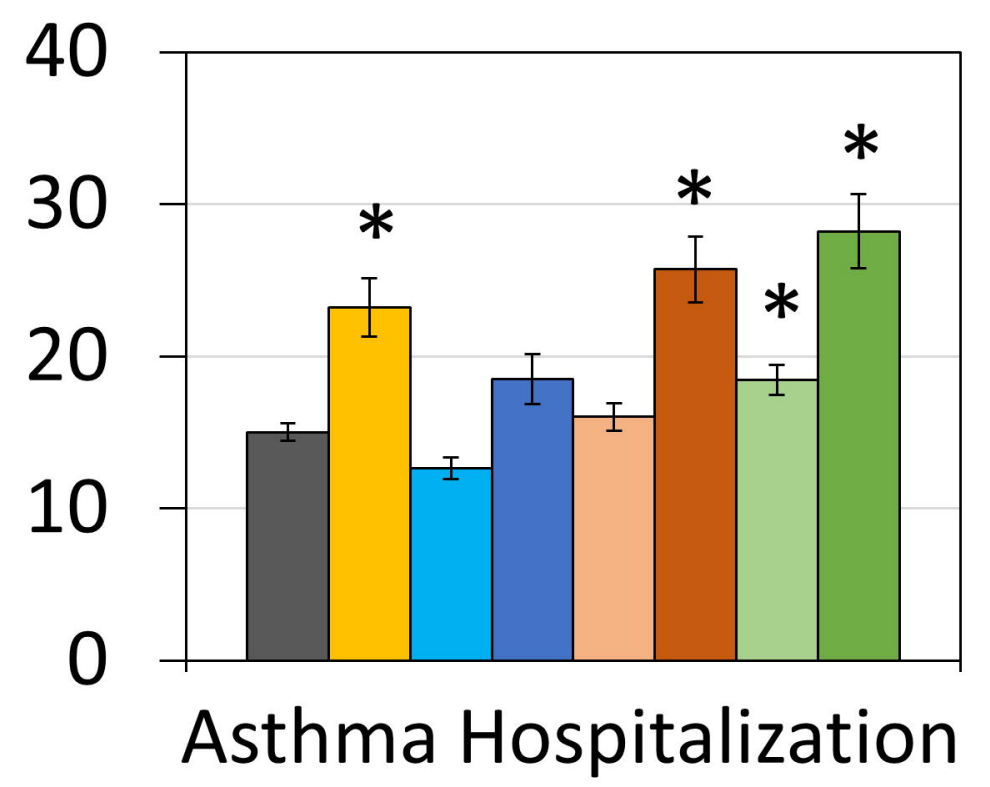

(2017-2019)

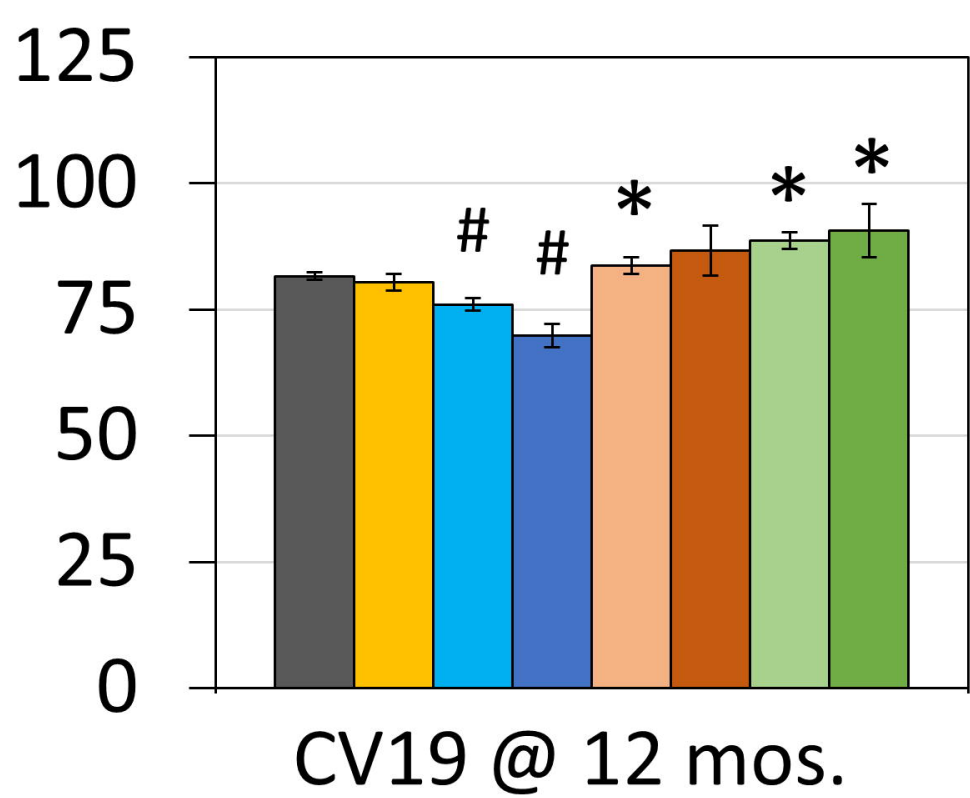

(Mar 2020-Mar 2021)

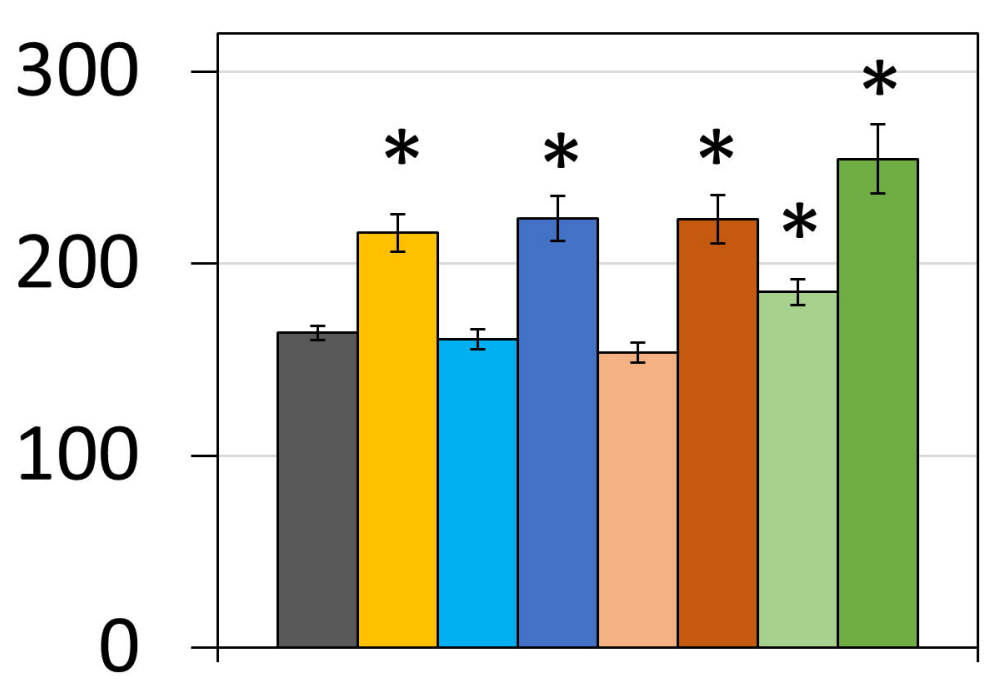

Est. Asthma Prevalence (2017-2019)
All CT

High SVI CTS

RHI

High RHI CTs

High SVI+RHI CTS

\section{PM2.5}

High PM2.5 CTs

High SVI+PM2.5 CTS

\section{Ozone (03)}

$\square$ High 03 CTs

$\square$ High SVI+O3 CTs

* Significantly higher \# Significantly lower (than "all CT") 
A) Overall SVI

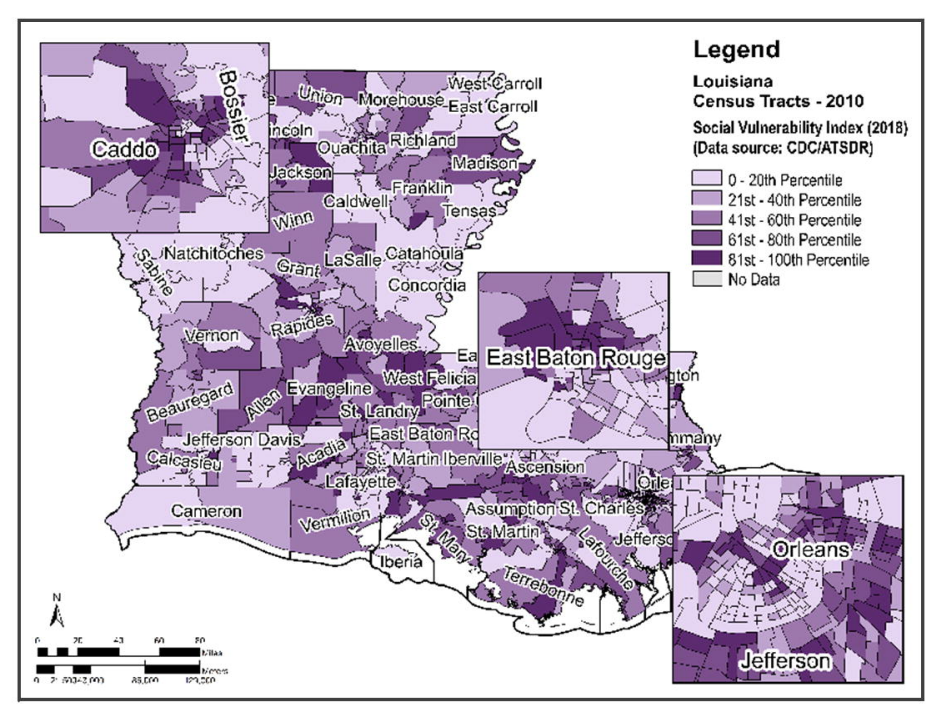

D) Indoor Mold Concerns

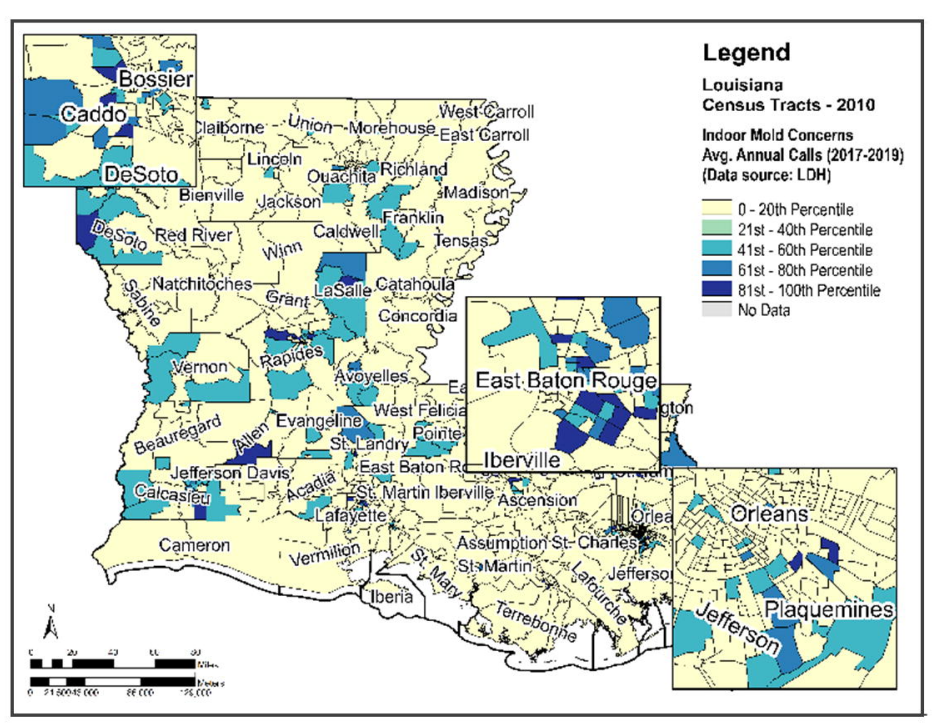

B)

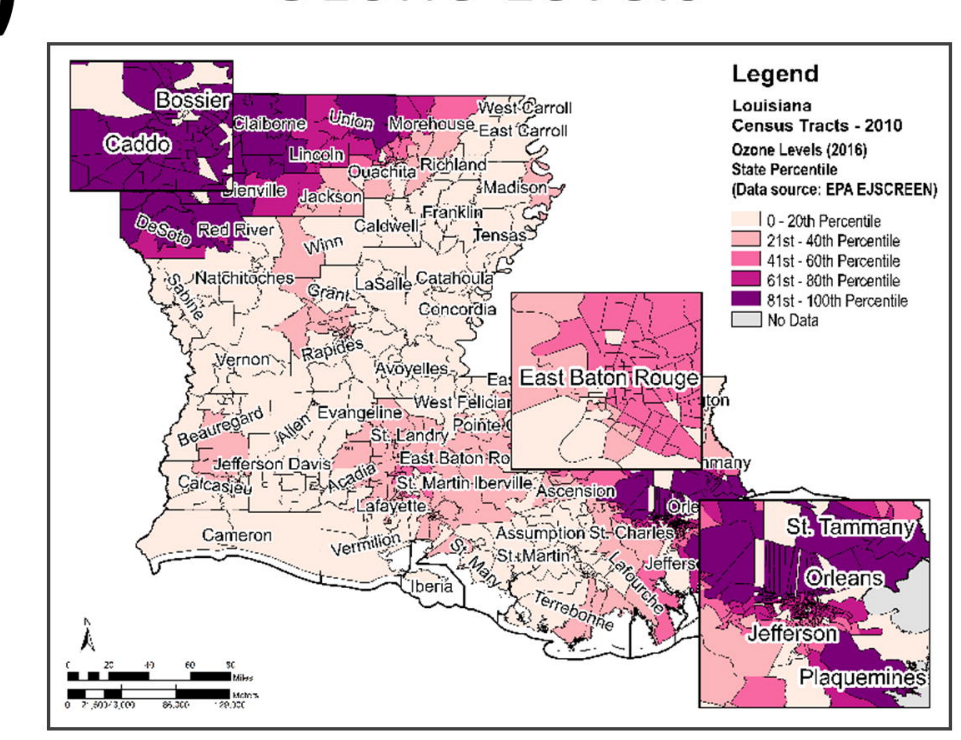

E) Est. Asthma Prevalence

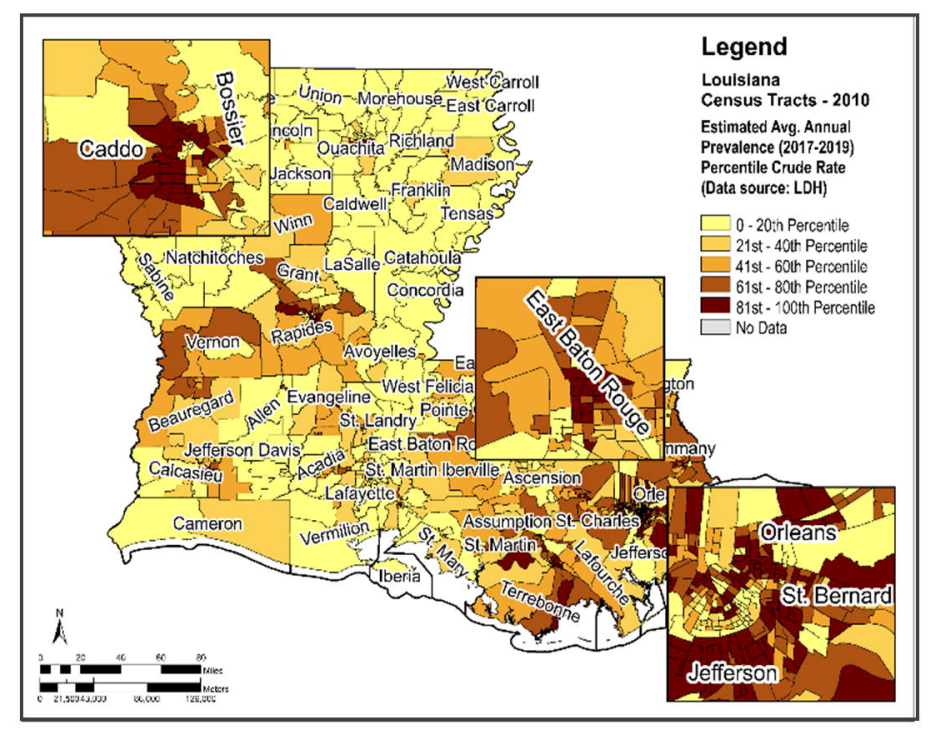

C)

PM2.5 Levels

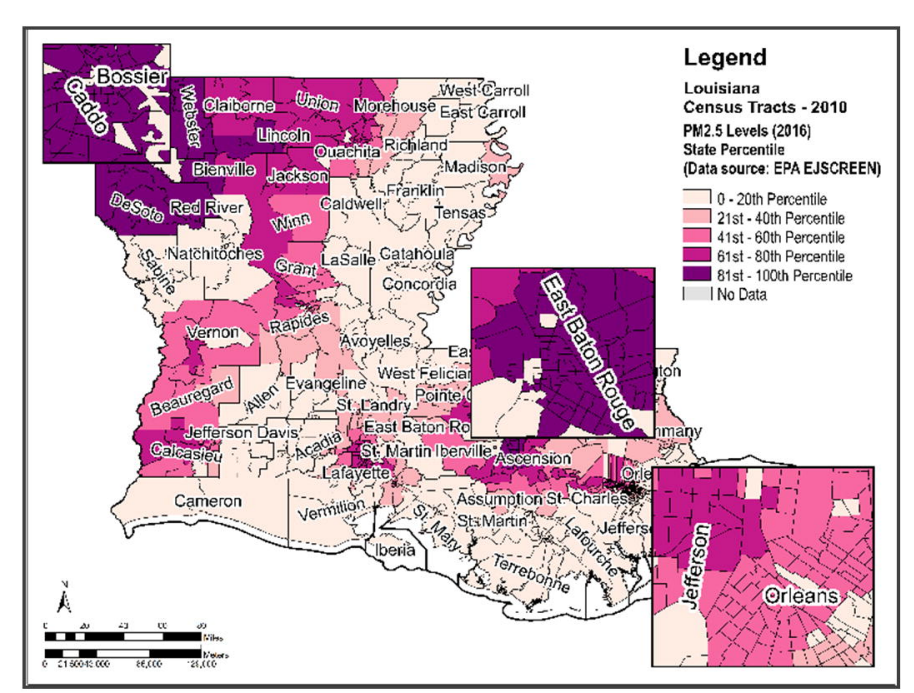

F) COVID-19 (12 months)

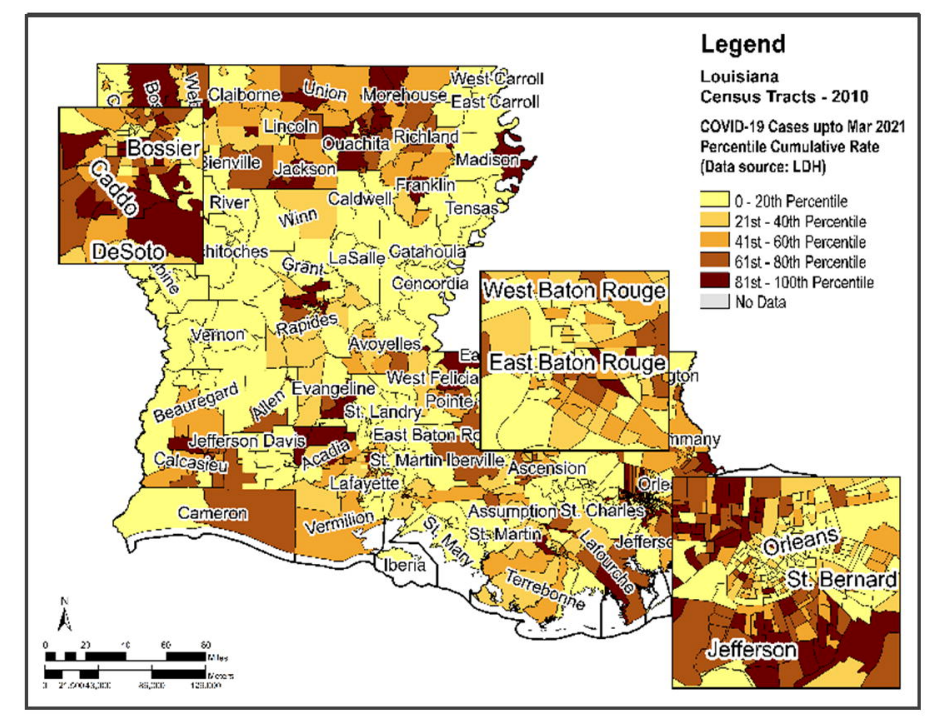


A) Intersection of Social \& Environmental Vulnerability

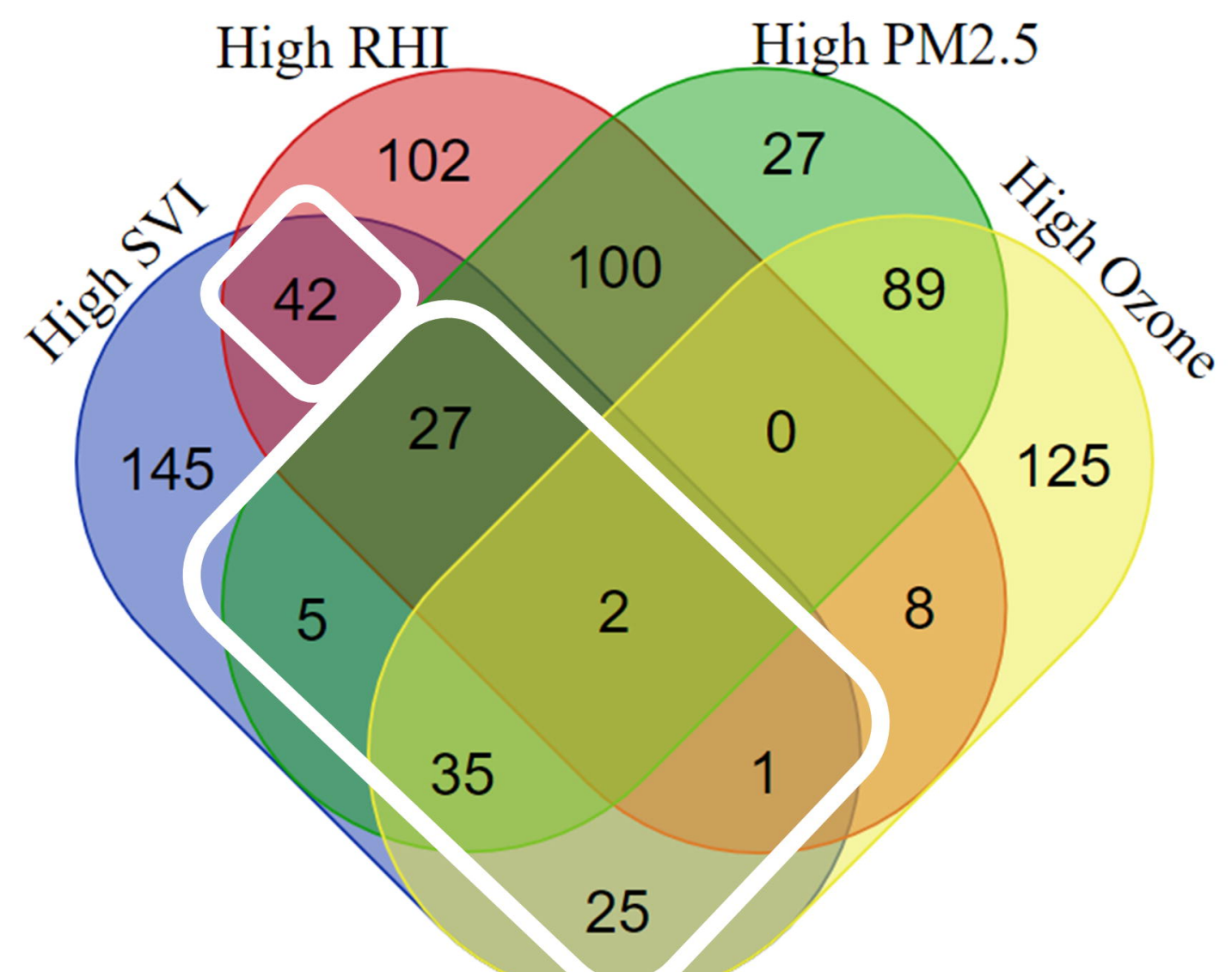

B) No. of CTs of EJ Concern by Parish

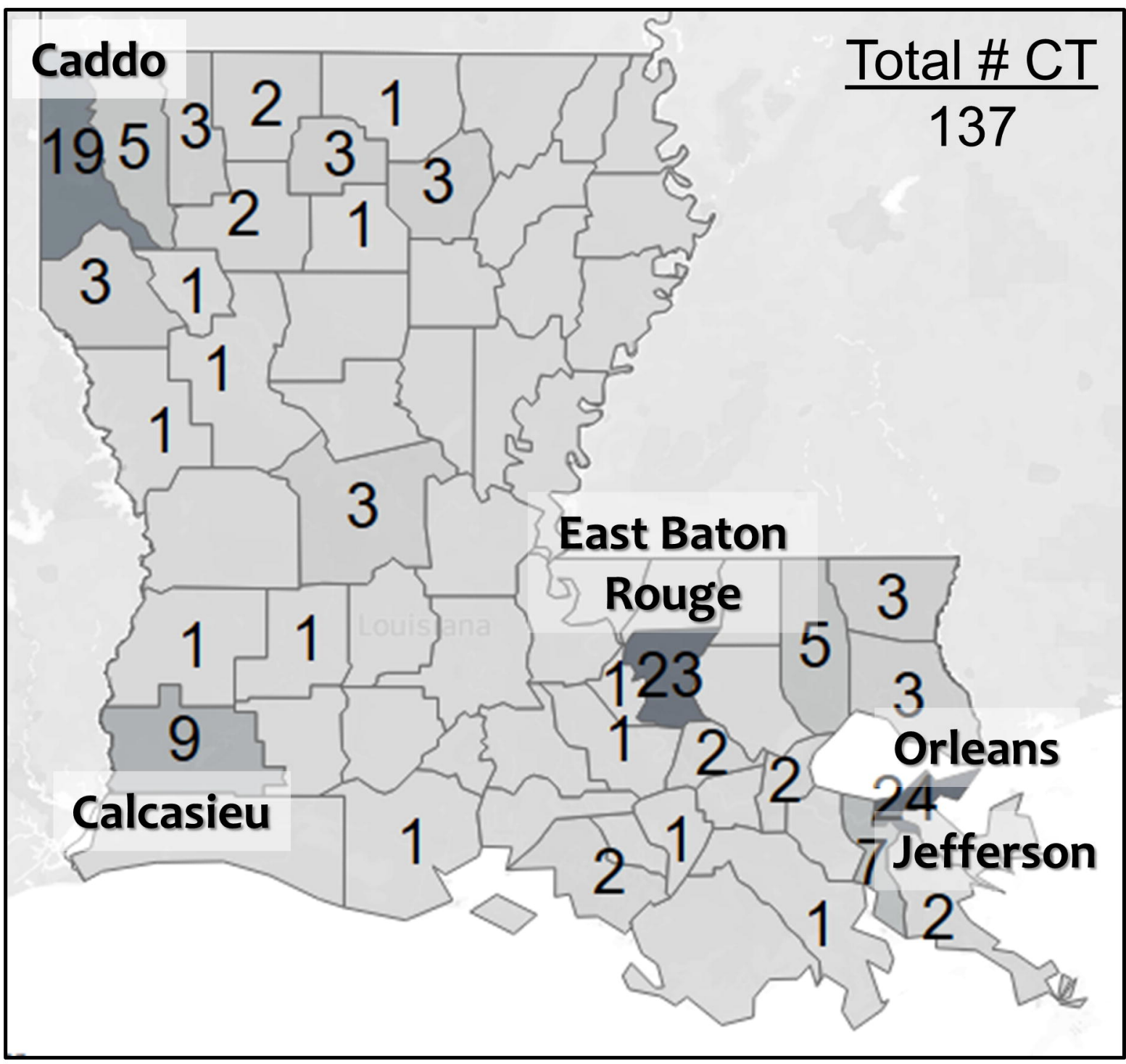


A) EJ Areas High Estimated Asthma Prevalence

B) No. of EJ CTs by Parish with B) high burden of asthma

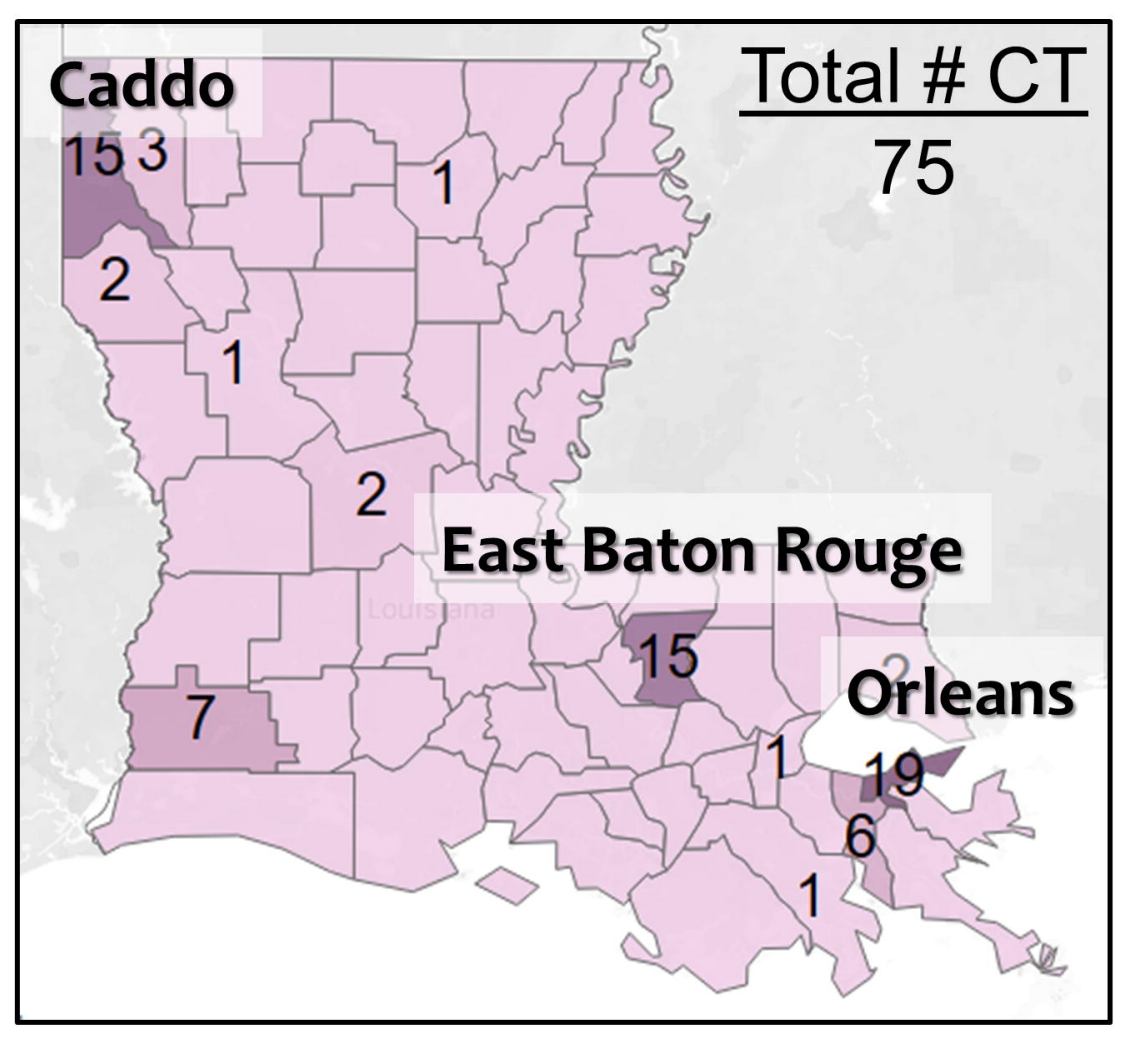

49

60

154

15

13

56

\section{5}

High Cumulative COVID-19 incidence (12 months)
No. of EJ CTs by Parish with high burden of

C) asthma and COVID-19

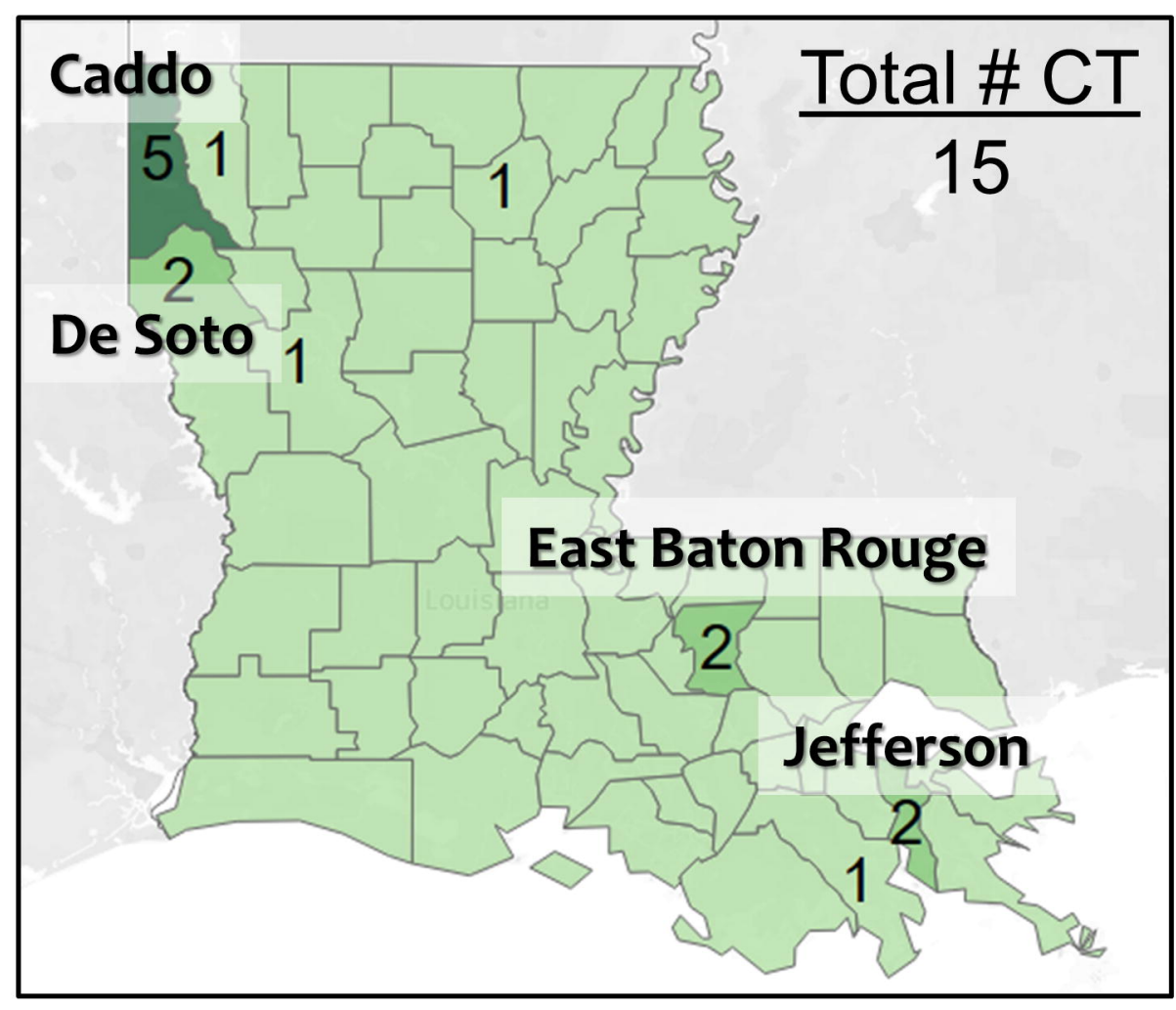

